Cahiers $d u$ MONDE RUSSE

\section{Cahiers du monde russe}

Russie - Empire russe - Union soviétique et États indépendants

$53 / 4 \mid 2012$

Varia

\title{
Aleksandr I. Andreev, Dany Savelli, eds., Rerikhi: Mify i fakty
}

\section{Susanna Soojung Lim}

\section{OpenEdition}

\section{Journals}

Electronic version

URL: http://journals.openedition.org/monderusse/7748

DOI: $10.4000 /$ monderusse. 7748

ISSN: $1777-5388$

\section{Publisher}

Éditions de l'EHESS

\section{Printed version}

Date of publication: 15 December 2012

ISSN: $1252-6576$

\section{Electronic reference}

Susanna Soojung Lim, «Aleksandr I. Andreev, Dany Savelli, eds., Rerikhi: Mify i fakty », Cahiers du monde russe [Online], 53/4 | 2012, Online since 02 December 2013, Connection on 25 September 2020 URL : http://journals.openedition.org/monderusse/7748; DOI : https://doi.org/10.4000/monderusse. 7748

This text was automatically generated on 25 September 2020.

(c) École des hautes études en sciences sociales 


\title{
Aleksandr I. Andreev, Dany Savelli, eds., Rerikhi: Mify i fakty
}

\author{
Susanna Soojung Lim
}

\section{REFERENCES}

Aleksandr I. ANDREEV, Dany SAVELLI, eds., Rerikhi: Mify i fakty. Sbornik statej [The Roerichs: Myths and Facts. A Collection of Essays]. St. Petersburg : Nestor-Istoria Publishers, 2011, 309 p.

1 Of the many prominent figures of early twentieth-century Russian culture, the painter, stage designer, explorer, writer, and creator of the Roerich Pact Nicholas Roerich (Nikolai Rerikh, 1874-1947) is one whose degree of prestige and cult-like popularity in post-Soviet Russia is curiously contrasted with his relative obscurity abroad. Nonetheless, following the explosion of interest in Roerich in Russia since the 1980s, and above all the significant influence of Agni Yoga, the spiritual movement created by Roerich and his wife Helen Roerich (Elena Rerikh, née Shaposhnikova, 1879-1955) in connection to the occult revival in post-Soviet culture, the artist's work and his ideas have begun to attract increasing attention in the West.

2 There is no dearth of literature dedicated to the life and work of the Roerichs; yet the bulk of the material tends to be marked by either unquestioned admiration for the couple as spiritual gurus, or else skirts aside uncomfortable issues that connect Roerich's art with the political and geopolitical context in which he lived. A more critical approach has been offered by Robert C. Williams in his Russian Art and American Money, 1900-1940 (1980), and, more recently, in articles by John McCannon, Alexandre Andreev's Gimalaiaskoe bratstvo: teosofskii mif $i$ ego tvortsy: dokumental'noe rassledovanie (2008), and Andrei Znamenski's Red Shambhala: Magic, Prophecy, and Geopolitics in the Heart of Asia (2011). To this body of critical research comes Rerihi: mify i fakty. Sbornik statei, edited by Alexandre Andreev and Dany Savelli and published by Nestor-Istoria Publishers, St. Petersburg (2011). Consisting of nine chapters preceded by a foreword, 
the volume contains the latest research on the Roerich couple based on previously unpublished archival documents by an international group of scholars from Russia, France, Canada, Japan, and Latvia. Abstracts of the chapters are presented at the end of the volume in Russian, French, and English.

In their foreword, the editors state that a main goal of the book was connected to the need for a serious scholarly analysis of Agni Yoga, of the religious project of the Roerichs during their period of emigration in the 1920s and 30s ("Ot redaktorovsostavitelei," p. 5). Arguing for a "kriticheskii istoriko-religiovedcheskii podkhod" that avoids the two extremes of a "cult-like veneration of the couple" or their "demonization," they write: "Gorazdo vazhnee analizirovat', nezheli sudit' slova i deiania Rerikhov. No dlia etogo neobkhodimo zadavat' voprosy i stavit' pod somnenie to, chto kazhetsia nesomnennym, a imenno: rerikhovskie mify (mifologemy) i vse to, chto Rerikhi rasskazyvali o samikh sebe i svoikh "kosmicheskikh Uchiteliakh" (p. 5-6).

4 Chapter one by Ivars Silars addresses the question of Nicholas Roerich's paternal ancestry ("Nicholas Roerich's Ancestors: Archives vs. Legends"). Researching the archives of Courland (Kurzeme, Latvia), Silars suggests that the largely accepted claim that the Roerichs are descendants of Rurik is unfounded. Instead, the family name Roerich originates from the German word das Röhricht (reed scrub) or the male name Roderich, which in turn points to a family history not of Varangian rulers, but of German craftsmen who settled in Courland.

Chapter two by Nadia Shchetkina-Rocher discusses the presence of kitsch in Roerich's art ("The appeal of kitsch in Roerich's aesthetics"). According to Shchetkina-Rocher, Roerich's early period was characterized by a conscious and deliberate use of kitsch (meta-kitsch), exemplified in the adoption of the postcard, the use of decorative elements, and the eclectic exoticism of his paintings. She claims, however, that following his religious transformation of the 1920s and his deepened messianism, Roerich's later works reflect a high-flown pompousness and didactic seriousness which (ironically) brings them closer to genuine kitsch.

6 Chapters three and four are by Aleksandr Andreev ("Occultism and Mysticism in the Life and Creative Work of Nicholas and Helena Roerich"; “Esther Lichtmann's Diaries: The Roerichs in Kulu (1929-1934)"). As the title of the lengthy third chapter indicates, Andreev (who in his Gimalaiskoe bratstvo examines the use of theosophy in the work of the Roerichs) deals directly with the thorny subject of occultism and mysticism in the lives of the Roerich couple and their spiritual and utopian ambitions. Beginning by situating the Roerichs within Russian fin de siècle's avid interest in spiritualism and the occult, he proceeds in several subsections ("Spiritizm i mahatmy"; "Velikii plan"; "Tvorchestvo Rerikhov-mistikov-proryv v potustoronnee"; "Ognennyi opyt E. Rerikh") to shed light on the origins of Helen Roerich's spiritual search, the couple's creation of Agni Yoga, their purported communication with Master Morya, their visions of the "Great Plan" and the "New Country," their grandiose geopolitical plans in relation to Russian, America, India, Tibet, the attempts to gain support from the political leaders of Soviet Russia and America, and, most important, Nicholas and Helen's selfmythologization as the great Russian prophet (guru) and the Russian Tara. In the end, Andreev argues, no cosmic teachers in fact existed, and the couple's Great Plan for world salvation is best understood as a form of myth creation.

7 Andreev continues to examine the element of myth creation in chapter four through the introduction of previously unpublished material, the diary of Esther Lichtman, a 
follower of the Roerich couple, written during Lichtman's two visits to their home in Kulu, India (1929-1934). Lichtman's diary gives us a first-hand look at Helen Roerich, the relationships and conflicts in the Roerich circle, and in addition provides insight to key events such as the British Indian authorities' denial of a visa to Nicholas Roerich in 1930 and the purported miracle involving the legendary "Buddha's Chalice" in the Roerich home in 1934.

8 In chapter five ("The Institutional Fortune of N.K. Roerich: The Example of the 'Association française des Amis du Roerich Museum' (1929-1935) through Unpublished Correspondence"), Dany Savelli draws attention to the worldwide network created by the Roerichs and their followers for the dissemination of his teachings and points to the need to study the institutionalization of Roerich manifest in the many organizations that bear his name. One such organization was the "Association française du Roerich Museum de New York" established in Paris in 1929 and serving as the European nerve of the central Roerich organization, the Nicholas Roerich Museum in New York. Similar to Andreev's chapters, Savelli highlights the utopian and mythmaking character of the Roerich project through her discussion of the difficulties faced by the Association's managers and the decline of Roerich's influence in Europe in the mid-1930s.

In chapter six, Yukiko Kitamura presents a brief survey of the publications on Roerich written in Japanese beginning in the 1920 s to 2006 . These include translations of Roerich's writings as well as articles and books about the artist by Japanese scholars such as Mitsueshi Numano. Kitamura also discusses Roerich's visit to Japan (1934) and the positive reception he received.

10 The paintings produced by Roerich during World War II (late 1930s and 1940s) is the subject of chapter seven by John McCannon. McCannon examines the various ideas and impulses that influenced the art of Roerich in this turbulent period, when the artist and his wife not only observed international developments with growing fear, but also faced the failure of the realization of their cherished Great Plan. The World War II paintings of Roerich speak of his antipathy to armed and his wish for a peaceful future of cosmic rejuvenation. Most important, his belief in Russia as the savior of nations develops, around 1937, into an urgent longing to return to his homeland. Given the notoriously inconsistent attitude towards Soviet Russia the Roerichs had exhibited since their emigration in the early 1920s, it is not surprising that the artist failed in his quest for repatriation. The paintings can be seen as a set of credentials addressed to the Soviet authorities in this ultimately vain attempt to return home.

11 Chapter eight examines the extraordinary impact of the Roerichs in late and post-Soviet society ("The Roerich Movement: A Unique Phenomenon of Post-Soviet Spirituality"). Noting that the wide popularity of Agni Yoga of the late 1980s and the 1990s and the many Roerich societies and organizations formed throughout Russia have never been subject to an "objective sociological analysis" (p. 236), authors Sergei Filatov and Roman Lunkin look at the ideology and character of this all-powerful Russian movement. They view the influence of the ideas of the Roerichs in post-Soviet society from several perspectives: the sacralization of culture, the adoption of Theosophy, Buddhism, and Christianity (as they rightly point out, this is not merely about the adoption of Eastern religions, but the syncretic combination of these with Orthodox Russian elements), the ideals of the Soviet epoch, and stereotypes of mass consciousness. 

Anita Stasulane provides an overview of the history of the Roerich movement in Latvia, which from the early 1920s to 1940 served as a center for the promotion and publication of Roerich's work in the Baltic region. Stasulane charts the evolution of the Roerich movement in Latvia following its reemergence in 1988, and examines the activity of its members manifest in three spheres of public life: culture, education, and politics.

13 As the summary of the chapters shows, Rerikhi: mify i fakty presents the reader with valuable new information and a wealth of details on the lives and work of the Roerichs. By its very approach the volume does much to dismantle the reverential halo surrounding the reception of the couple and to place their work in a historical and cultural context. However, the structure and organization of the many chapters feels haphazard and incongruous, and, as a result, does little justice to the rich content. One wishes that the volume as a whole corresponded more clearly and fully to its professed aim of addressing the tension between myth and fact in the work of the Roerichs, as stated by the editors in their foreword. While the chapters by Andreev, Filatov/Lunkin, and, to a lesser extent, Savelli, offer in-depth analyses of this issue, the chapters by Kitamura and Stasulane, on the other hand, are more explanatory and survey-like in nature.

In addition, inasmuch as the volume is dedicated to the Roerichs as a couple, rather than Nicholas Roerich alone, a stronger focus on Helen Roerich and a discussion of the nature of the collaboration of husband and wife would have been fitting. Although the role of Helen Roerich is partly discussed in the chapters by Andreev and Filatov/ Lunkin, one or two chapters on Helen Roerich per se would have been germane, especially given that the Roerichs' religious project is more directly connected to her. On a formal note, a brief chronology of the Roerichs and/or a bibliography of available critical literature on the Roerichs would have been useful.

These points notwithstanding, in sum Rerikhi: mify i fakty is a welcome addition to the literature devoted to the work and impact of Nicholas and Helen Roerich. The research offered points to yet further intriguing directions in Roerich studies: the Orientalism of the Roerichs, the Soviet Union's relationship with the East (India, Tibet), the Roerichs as an example of myth-creation, Helen Roerich, and the impact of the occult in Russia today.

Cahiers du monde russe, 53/4 | 2012 